February 2005 • NREL/CP-520-37405

\title{
InGaAs/GaAs QD Superlattices: MOVPE Growth, Structural and Optical Characterization, and Application in Intermediate-Band Solar Cells
}

\author{
A.G. Norman, M.C. Hanna, P. Dippo, D.H. Levi, \\ R.C. Reedy, J.S. Ward, and M.M. Al-Jassim
}

Prepared for the $31^{\text {st }}$ IEEE Photovoltaics Specialists Conference and Exhibition Lake Buena Vista, Florida January 3-7, 2005
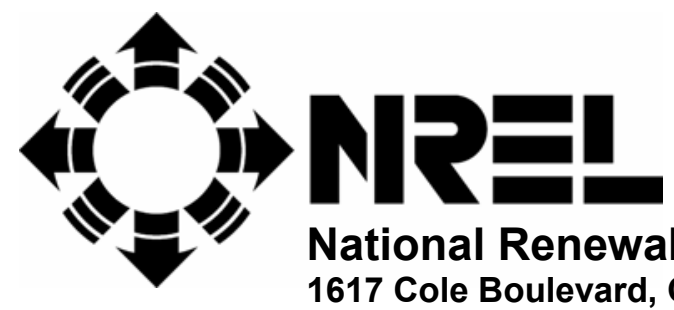

National Renewable Energy Laboratory 1617 Cole Boulevard, Golden, Colorado 80401-3393 303-275-3000 • www.nrel.gov

Operated for the U.S. Department of Energy Office of Energy Efficiency and Renewable Energy by Midwest Research Institute $\bullet$ Battelle 


\section{NOTICE}

The submitted manuscript has been offered by an employee of the Midwest Research Institute (MRI), a contractor of the US Government under Contract No. DE-AC36-99G010337. Accordingly, the US Government and MRI retain a nonexclusive royalty-free license to publish or reproduce the published form of this contribution, or allow others to do so, for US Government purposes.

This report was prepared as an account of work sponsored by an agency of the United States government. Neither the United States government nor any agency thereof, nor any of their employees, makes any warranty, express or implied, or assumes any legal liability or responsibility for the accuracy, completeness, or usefulness of any information, apparatus, product, or process disclosed, or represents that its use would not infringe privately owned rights. Reference herein to any specific commercial product, process, or service by trade name, trademark, manufacturer, or otherwise does not necessarily constitute or imply its endorsement, recommendation, or favoring by the United States government or any agency thereof. The views and opinions of authors expressed herein do not necessarily state or reflect those of the United States government or any agency thereof.

Available electronically at http://www.osti.gov/bridge

Available for a processing fee to U.S. Department of Energy and its contractors, in paper, from:

U.S. Department of Energy

Office of Scientific and Technical Information

P.O. Box 62

Oak Ridge, TN 37831-0062

phone: 865.576 .8401

fax: 865.576.5728

email: mailto:reports@adonis.osti.gov

Available for sale to the public, in paper, from:

U.S. Department of Commerce

National Technical Information Service

5285 Port Royal Road

Springfield, VA 22161

phone: 800.553 .6847

fax: 703.605.6900

email: orders@ntis.fedworld.gov

online ordering: http://www.ntis.gov/ordering.htm 


\title{
InGaAs/GaAs QD SUPERLATTICES: MOVPE GROWTH, STRUCTURAL AND OPTICAL CHARACTERIZATION, AND APPLICATION IN INTERMEDIATE-BAND SOLAR CELLS
}

\author{
A. G. Norman, M. C. Hanna, P. Dippo, D. H. Levi, R. C. Reedy, J. S. Ward, and M. M. Al-Jassim \\ National Renewable Energy Laboratory (NREL), 1617 Cole Boulevard, Golden, CO 80401
}

\begin{abstract}
We report on the growth and characterization of InGaAs/GaAs quantum dot (QD) superlattices for application in intermediate-band solar cells (IBSCs). Good optical and structural quality QD superlattices with up to 50 periods were obtained by metal-organic vapor-phase epitaxy (MOVPE) growth on $\{113\} B$ GaAs substrates. Solar cells containing $\mathrm{Si} \partial$-doped and undoped QD superlattice absorption regions have been fabricated and their performance compared with control cells containing undoped $\mathrm{GaAs}$ or undoped InGaAs/GaAs superlattice absorption regions. The QD superlattice cells exhibited photoresponses extended to longer wavelengths than the control cells. The introduction of QDs to the absorbing region of the solar cells resulted in a decrease in the opencircuit voltages and, in some cases, a decrease in the short-circuit currents of the cells.
\end{abstract}

\section{INTRODUCTION}

In the future, materials costs and availability are likely to drive the evolution of photovoltaic technology toward cells performing at the highest possible efficiencies [1,2]. New concepts will be required to produce this 'third generation' of low-cost, high-performance PV devices $[1,2]$. One of the largest losses associated with conventional single-junction solar cells is that subbandgap photons do not contribute to the device current. Luque and Marti $[3,4]$ proposed increasing the efficiency of ideal solar cells by using an intermediate band lying inside the forbidden energy gap of the semiconductor host material to absorb photons with energies below the semiconductor bandgap. The states within the intermediate band need to be partially filled to provide good absorption. This is so an electron from the valence band can be excited to an unoccupied level in the intermediate band, from which it or another electron can then be excited to the conduction band (see Fig. 1). By this mechanism, the absorption of two photons of low energy can result in an electron-hole pair of higher energy than the semiconductor host-material bandgap. The electrons in the conduction band generated by this process add to those generated by the normal one-step absorption process across the barrier semiconductor material bandgap, thus adding extra current flow in the device. If the cell is properly contacted, these extra electrons can be extracted at a high voltage limited only by the bandgap of the barrier material. Assuming optimal

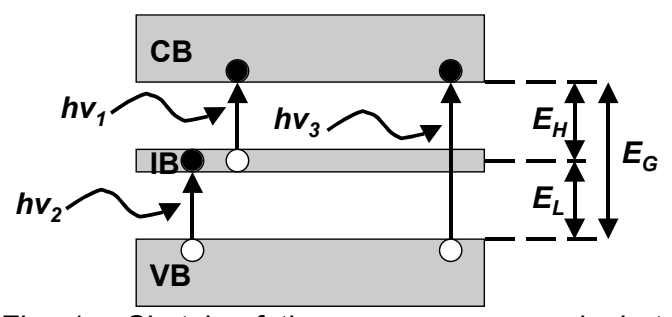

Fig. 1. Sketch of the energy gaps and photon absorption processes involved in the operation of an intermediate band solar cell.

photon selectivity, they showed that the limiting efficiency was as high as $63.2 \%$ under maximum concentration conditions at $300 \mathrm{~K}$ (sun assumed to be a black body at $6000 \mathrm{~K}$ ), which is much greater than the $40.7 \%$ limiting efficiency of a conventional single-gap solar cell under the same operating conditions. Under the above conditions, the optimum values of the gaps (see Fig. 1) were predicted to be $E_{L}=0.71 \mathrm{eV}, E_{H}=1.24 \mathrm{eV}$, and $E_{G}=1.95$ $\mathrm{eV}$.

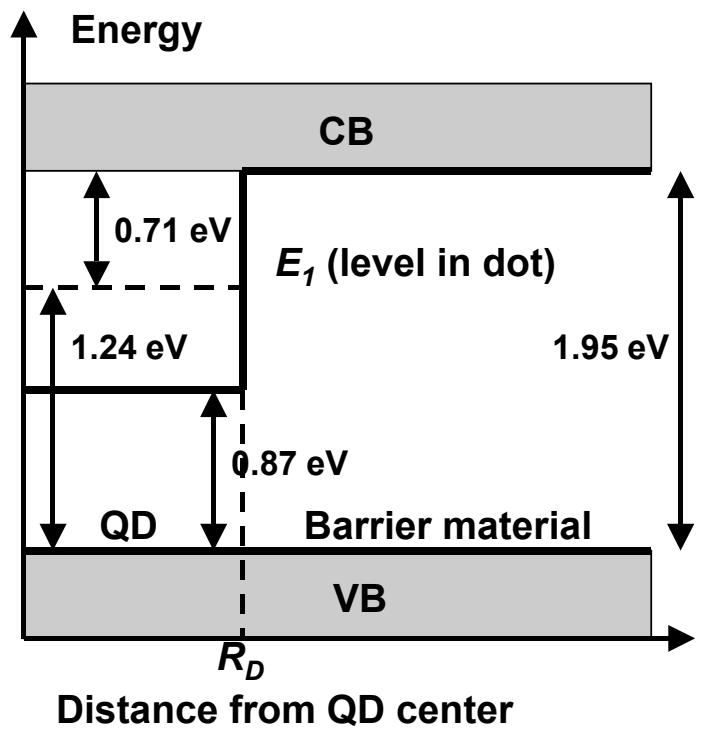

Fig. 2. Simplified band structure of ideal spherical QD in QD intermediate-band solar cell [5].

Marti et al. [5-8] proposed realizing the concept of an IBSC by using QD technology. In a small-bandgap QD surrounded by a higher-bandgap barrier material, the wave function of an electron can be confined to discrete 


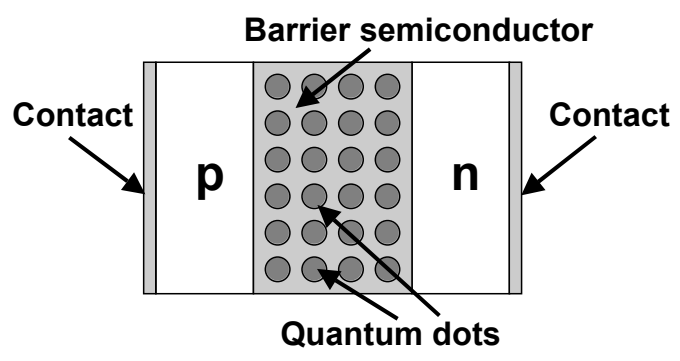

Fig. 3. Schematic of the QD intermediate band solar cell.

energy levels (see Fig. 2). The position of these levels can be tuned by controlling the size of the QD. In Fig. 2, the top of the valence band (VB) has been assumed to be the same in the QD and barrier semiconductor material, and band bending due to space-charging effects has been ignored. The optimum barrier material bandgap of 1.95 $\mathrm{eV}$ is shown. In this example, electrons confined in the QD have a single energy level $E_{1}$ lying at $0.71 \mathrm{eV}$ below the conduction band (CB) edge produced by a potential well depth of $1.08 \mathrm{eV}$ below the $\mathrm{CB}$ edge resulting from a QD material of bandgap $0.87 \mathrm{eV}$ [5]. AlGaAs barriers and InGaAs QDs are potential materials to produce such a band structure. Ideally, however, one would prefer a combination of $\mathrm{QD}$ and barrier materials with a zero VB offset, because a non-zero $V B$ offset will result in a reduction in the open-circuit voltage of the final QD IBSC [9]. If the QDs form an ordered 3D array, packed close enough together such that the wave functions of the carriers in the individual QDs overlap with each other, then the discrete energy levels of a single QD broaden to become mini-bands. A mini-band at the appropriate energy position can then act as the intermediate band required for an IBSC. A close-packed 3D array of QDs is also required for a high absorption coefficient. A schematic of the proposed QD IBSC device structure is shown in Fig. 3.

A possible way of obtaining the ordered $3 D$ array of QDs required for the QD IBSC is by the strain-induced Stranski-Krastanov growth process [10,11]. Growth of a coherently strained epitaxial layer results in the formation of strained islands after a certain critical thickness; this is driven by a reduction in the total energy. These strained islands of a narrow-bandgap semiconductor form QDs when surrounded by a higher bandgap barrier semiconductor material. A single layer of these strained islands forms a 2D array of QDs that can show some lateral ordering $[11,12]$. A 3D array of QDs is then formed by vertical stacking of $2 \mathrm{D}$ arrays of QDs separated by thin barrier layers. Strain coupling between adjacent $Q D$ layers can result in an ordered vertical stacking of the QDs and the formation of a $3 D \mathrm{QD}$ array or $\mathrm{QD}$ superlattice (SL) $[11,13]$.

In this work, we have chosen to grow by low-pressure MOVPE InGaAs/GaAs QD superlattices (SLs) as a model system to test the concept of the IBSC. GaAs was chosen as the barrier material (rather than the more optimum bandgap AIGaAs) because of the large difference in growth temperature required to grow good-quality $\mathrm{AIGaAs}$ and InGaAs QDs by MOVPE.

\section{EXPERIMENTAL}

InGaAs/GaAs QD SLs, containing up to 50 periods, have been grown by low-pressure MOVPE on both (001) and $\{113\} \mathrm{B} \quad \mathrm{GaAs}$ substrates. Triethylgallium, trimethylindium, and arsine were used as sources for the MOVPE growth. The growth temperature was $550^{\circ} \mathrm{C}$ and the QD composition was aimed to be $\ln _{0.47} \mathrm{Ga}_{0.53} \mathrm{As}$. Annealing under $\mathrm{H}_{2}$ after the growth of each InGaAs QD layer was found to be essential in order to grow goodquality QD SLs. The microstructure of the QD SLs was characterized by atomic force microscopy (AFM), transmission electron microscopy (TEM) and $x$-ray diffraction. The optical properties of the samples were assessed by photoluminescence (PL) and absorption measurements. Pin device structures incorporating Si $\partial$ doped or undoped QD SL absorbing regions have been grown and processed into mesa-type cells with 2-mmdiameter circular active regions. External quantum efficiency (EQE) and current-voltage (IV) measurements have been made from several cells on each wafer, and the results were compared to measurements performed on control cells with identical device structures (except for containing undoped GaAs or undoped InGaAs/GaAs SL absorbing regions).

\section{RESULTS}

\section{Growth and characterization of QD SLs}

To obtain high-quality QD SLs, it was found that the MOVPE growth conditions are critical, particularly the gasswitching procedures used at the end of growth of the InGaAs QD layers. Pausing under $\mathrm{AsH}_{3}$ for $1 \mathrm{~s}$ after the growth of each InGaAs QD layer resulted in only a low density of large InGaAs islands after growth of several periods of the QD SLs, particularly on (001) substrates. Incorporating a $30 \mathrm{~s}$ anneal under $\mathrm{H}_{2}$ after each $\mathrm{QD}$ layer

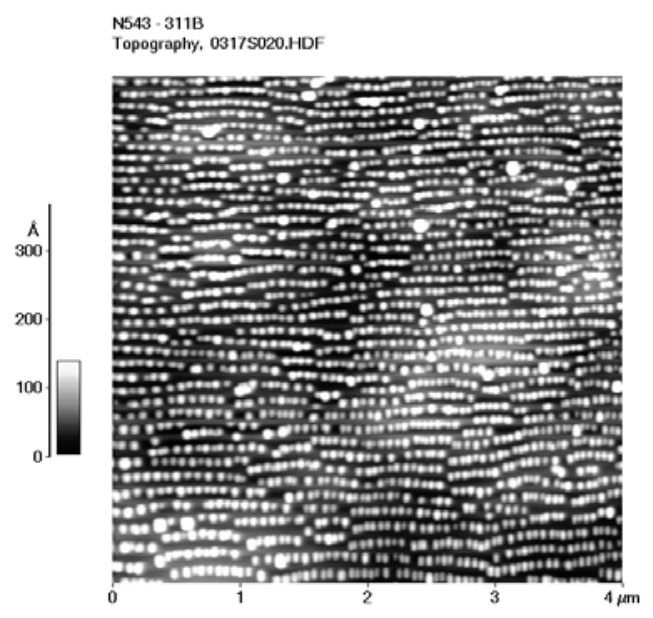

Fig. 4. AFM image of a 50-period undoped InGaAs (6.1 ML)/GaAs (20 nm) QD SL grown on \{113\}B GaAs substrate. 


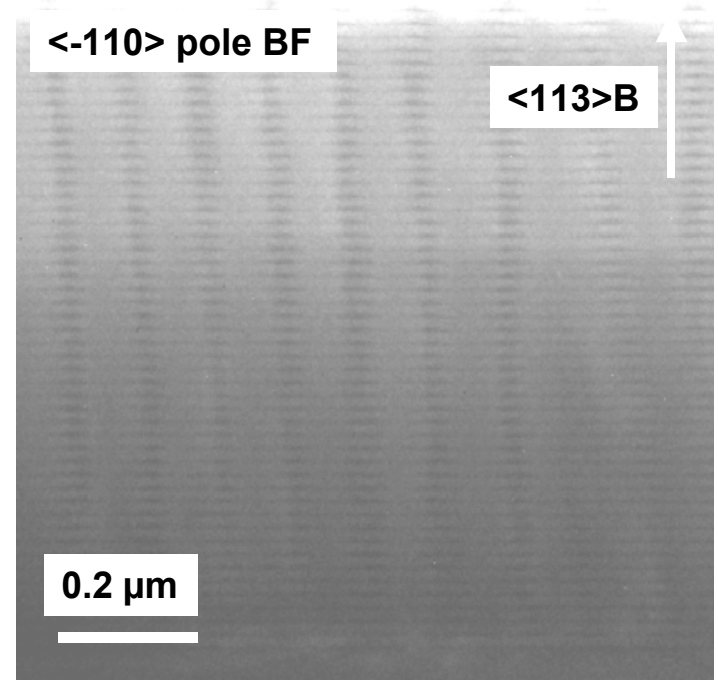

Fig. 5. <-110> pole bright-field TEM cross-section image of a 50-period undoped InGaAs (6.1 $\mathrm{ML}) / \mathrm{GaAs}(20 \mathrm{~nm}) \mathrm{QD} \mathrm{SL}$ grown on \{113\}B GaAs substrate.

was found to result in a much higher quality QD SL for growth on $\{113\} B$ substrates. Using these conditions, good lateral ordering of QDs occurred, as was determined by AFM on a 50-period QD SL (see Fig. 4). Ordered chains of QDs were present and aligned along [-110] on the $\{113\} B$ surface. The QDs had a number density of $10^{10} \mathrm{~cm}^{-2}$. The same growth conditions for QD SLs on (001) substrates, however, resulted in clusters of InGaAs QDs on top of surface mounds. QD SLs grown on $\{113\} B$ substrates using the $\mathrm{H}_{2}$ anneals showed very good vertical

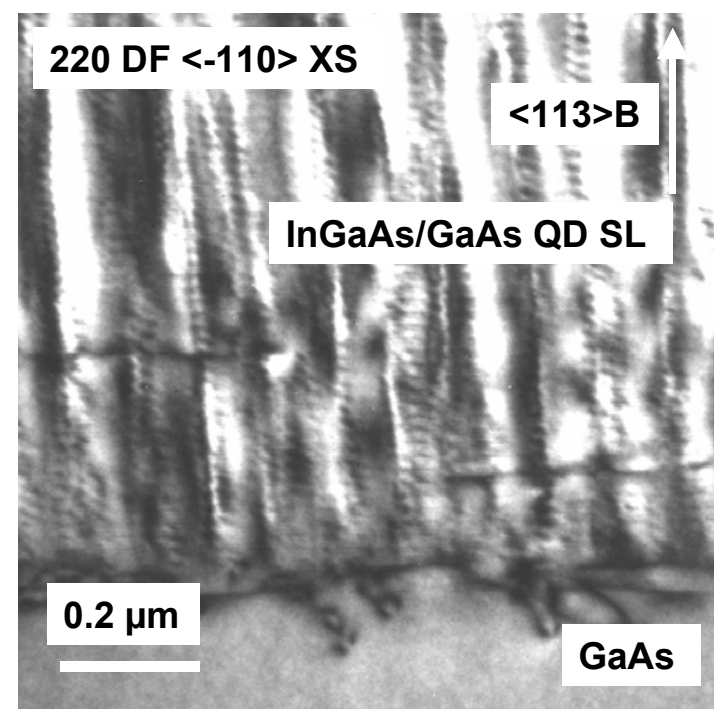

Fig. 6. 220 dark-field TEM cross-section image of a 50-period undoped InGaAs (6.1 ML)/GaAs (20 nm) QD SL grown on $\{113\} B$ GaAs substrate. Misfit dislocations are present at InGaAs/GaAs QD SL-GaAs interface.

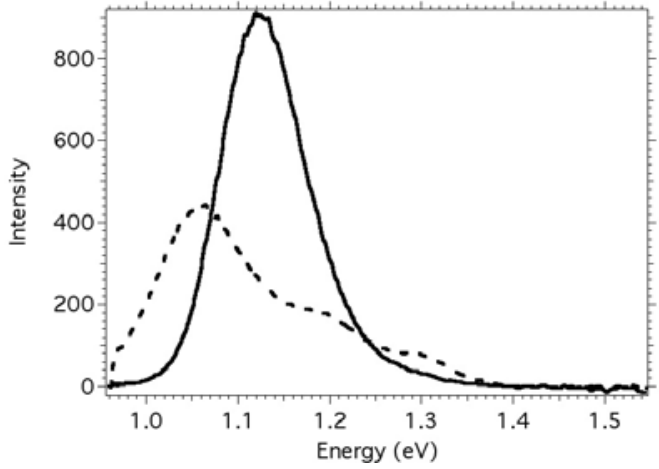

Fig. 7. Room-temperature PL spectra of 50 period InGaAs/GaAs QD SLs grown on $\{113\} B$ GaAs (solid line) and (001) GaAs (dashed line) substrates.

stacking of the QDs along the [113] growth direction when examined by cross-sectional TEM (see Fig. 5). In comparison, the QD SLs grown on (001) substrates using the same conditions exhibited little vertical stacking of QDs.

In QD SLs containing 25 and 50 periods, the misfit strain associated with the InGaAs QD layers resulted in the introduction of misfit dislocations (see Fig. 6). Such lattice defects are liable to result in a degradation of optical properties and a reduction in minority-carrier lifetimes and thus could reduce the performance of solar cells fabricated from such QD stacks.

The optical properties of the QD stacks were assessed by PL. Room-temperature PL spectra of 50period undoped QD stacks grown using $\mathrm{H}_{2}$ pauses after

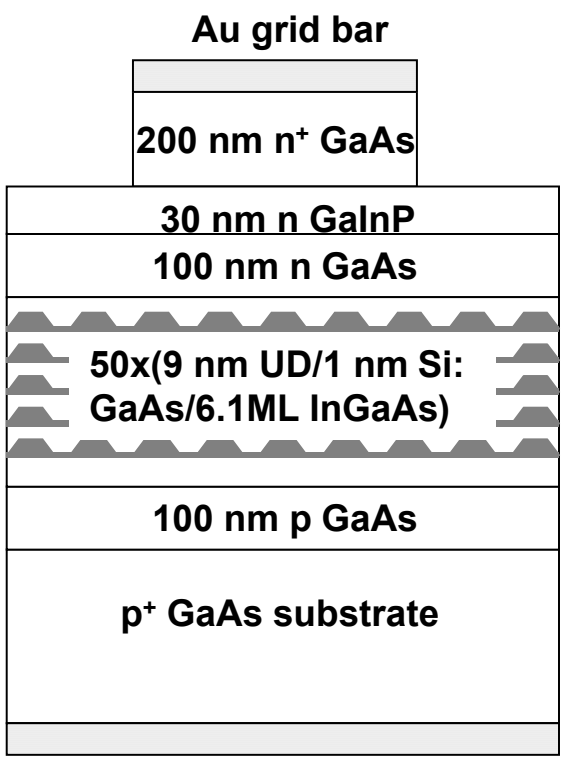

\section{Au contact}

Fig. 8. Schematic diagram of QD IBSC device structure containing a 50-period Si $\partial$-doped InGaAs/GaAs QD SL absorbing region. 


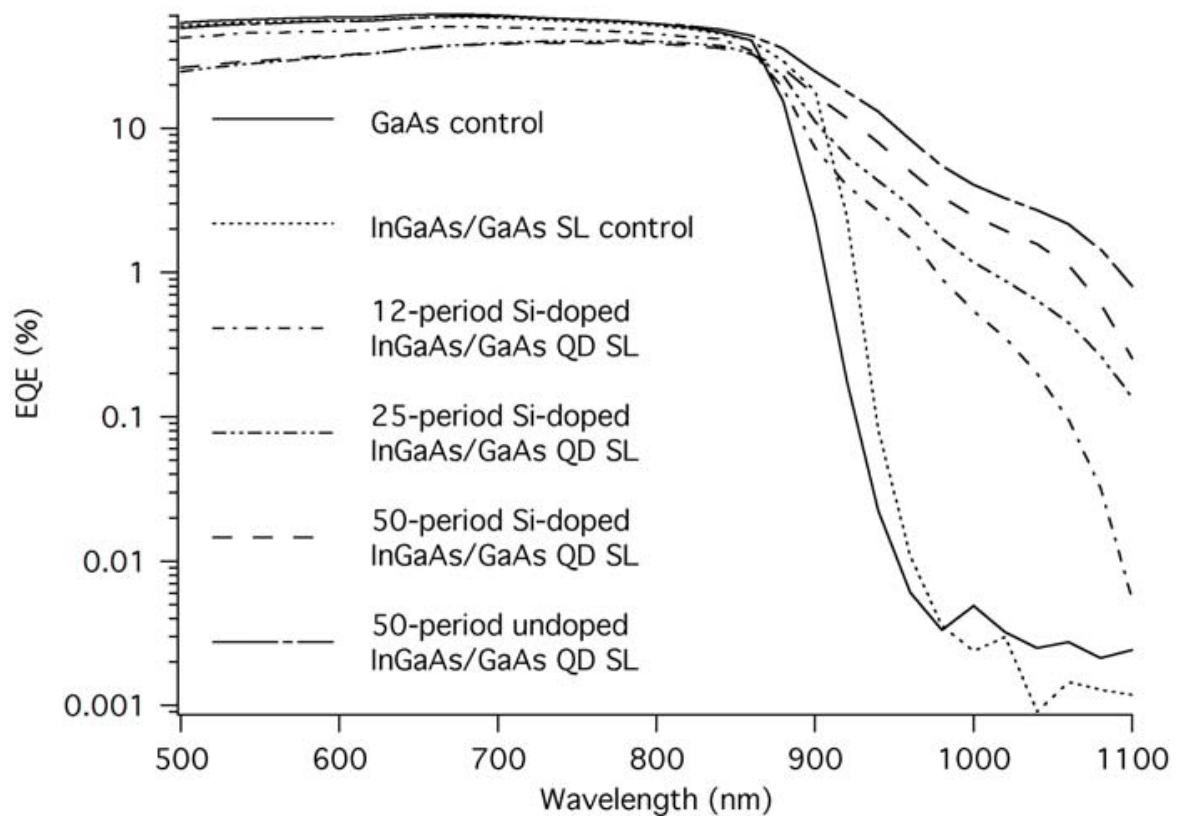

Fig. 9. External quantum efficiencies of InGaAs/GaAs QD SL cells and InGaAs/GaAs

$\mathrm{SL}$ and $\mathrm{GaAs}$ control cells grown on $\{113\} \mathrm{B} \mathrm{GaAs}$ substrates.

growth of the InGaAs QD layers are shown in Fig. 7. Despite the presence of misfit dislocations, the sample grown on $\{113\} B$, which contains a good-quality wellordered QD SL (see Figs. 4 and 5), shows a single intense peak at an energy of $1.12 \mathrm{eV}$. The sample grown on (001) that contained a very poor quality QD SL exhibited multiple PL peaks of lower intensity.

\section{Growth, fabrication, and characterization of QD solar cells}

Test solar cell pin devices have been grown and fabricated that incorporate $\mathrm{Si} \partial$-doped and undoped InGaAs/GaAs QD SL absorbing regions. A typical device structure is shown in Fig. 8. The wafers were processed into an array of small isolated mesa-type cells with a 2$\mathrm{mm}$-diameter circular active region. The absorbing region thickness was kept constant at $0.5 \mu \mathrm{m}$ by adjusting the barrier layer thickness in QD SLs consisting of 12, 25, and 50 periods. The performance of these QD solar cells was compared with control cells having an identical device structure, but without the QD layers. One control cell contained an undoped GaAs absorbing region. The other control cell contained an absorption region consisting of an undoped SL of thin two-dimensional strained InGaAs quantum wells separated by thin GaAs barrier layers; to determine the effect of thin two-dimensional InGaAs wetting layers present in the QD SL samples on cell performance.

EQE measurements were performed on several cells of each processed wafer using a calibrated Si cell as a reference cell. No antireflection coatings were used on the devices. Some typical results obtained for different device structures grown on $\{113\} B$ substrates are shown in Fig. 9. The InGaAs/GaAs SL control cell exhibits a photoresponse extended to slightly longer wavelengths than the GaAs control cell. All the QD SL cells have photoresponses extended to longer wavelengths than both the control cells. Luque et al. [14] recently reported a similar extended photoresponse for a 10-period Si $\partial$ doped InAs/GaAs QD IBSC device grown by molecular beam epitaxy. It is clear from our results that an increase in the number of QD SL periods in the absorbing region of Si $\partial$-doped QD SL devices results in an increase in the EQE at long wavelengths. A 50-period undoped QD SL exhibited a higher EQE at longer wavelengths than the equivalent $\mathrm{Si} \partial$-doped structure (almost $1 \%$ still at a wavelength of $1100 \mathrm{~nm}$ ).

IV measurements have been performed on several cells from each processed wafer. These measurements were performed at $25^{\circ} \mathrm{C}$ under an AM1.5G spectrum at an irradiance of $1000 \mathrm{~W} / \mathrm{m}^{2}$ using a XT10 solar simulator. A Si reference cell was used to calibrate the illumination level. Some typical light-IV results obtained for different device structures grown on $\{113\} B$ substrates are shown in Fig. 10. The QD SL solar cells show reduced opencircuit voltages $\left(\mathrm{V}_{\mathrm{OC}}\right)$ in comparison to the control cells. For Si $\partial$-doped QD cells, the $\mathrm{V}_{\mathrm{OC}}$ decreases as the number of periods is increased in the QD SL absorption region. Si $\partial$-doped QD cells containing 25 and 50 periods also exhibited much reduced short-circuit current densities $\left(\mathrm{J}_{\mathrm{SC}}\right)$ in comparison to the control cells and a 12-period $\mathrm{Si}$ d-doped QD cell. Interestingly, a 50-period undoped QD cell had a $\mathrm{J}_{\mathrm{SC}}$ comparable to the control cells.

\section{DISCUSSION}

The IV measurements indicate that the addition of a QD SL in the absorbing region reduces the $V_{O C}$ of the cells. One of the causes of this is probably due to the VB offset between the InGaAs QDs and the GaAs barrier layers. If a large $V B$ offset is present it leads to the 


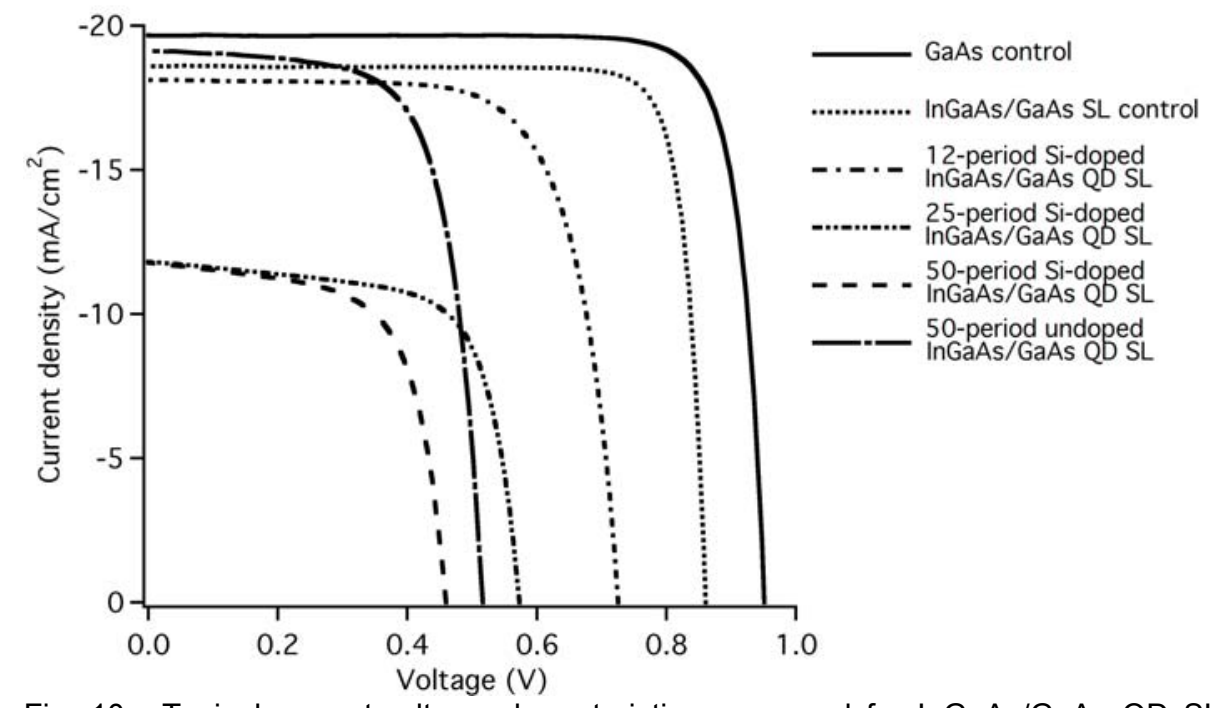

Fig. 10. Typical current-voltage characteristics measured for InGaAs/GaAs QD SL cells and InGaAs/GaAs SL and GaAs control cells grown on $\{113\} \mathrm{B}$ GaAs substrates.

introduction of a high number of closely spaced hole levels into the QD VB with a separation < kT that can overlap with the barrier layer VB continuum. This can enable easy, rapid relaxation of holes, through phonon interaction, from the VB continuum to the hole minibands in the QDs. This will result in a reduction of the $\mathrm{V}_{\mathrm{OC}}$ of the cell of close to the value of the VB offset. The VB offsets for InGaAs strained to GaAs were calculated by Kim et al. [15]. For $\operatorname{In}_{0.47} \mathrm{Ga}_{0.53} \mathrm{As}$ strained to $\mathrm{GaAs}$, they predict a VB offset of about $\sim 0.23 \mathrm{eV}$. In the case of our 50-period QD SLs, we see a reduction in $V_{O C}$ of $0.45-0.5 \mathrm{eV}$. Other sources for the reduction in $V_{O C}$ of these SLs with a high number of periods could be segregation of In into the barrier layers forming lower bandgap InGaAs alloy barriers or increased recombination in the devices associated with the quantum dots and the high density of misfit dislocations present in some samples. Alternatively, electrons from the $\mathrm{CB}$ of the barrier material may be rapidly relaxing to the $Q D$ IB by the emission of phonons causing the $C B$ electron gas to collapse and no longer be well separated from the IB electron gas. This means that the $\mathrm{CB}$ electron gas will no longer have its own quasiFermi level well separated from the IB electron gas quasiFermi level resulting in a reduction in the $\mathrm{V}_{\mathrm{OC}}$. To overcome the reduction in $V_{O C}$ due to the $V B$ offset, a new QD/barrier materials system with as low a VB offset as possible is probably required. Honsberg and Levy [9] have recently identified InAsSb or InPSb QDs in AIAsSb barriers as potential materials systems with very low VB offsets.

In the 25- and 50-period Si $\partial$-doped QD SLs, a large reduction in $\mathrm{J}_{\mathrm{SC}}$ was measured in comparison to a 12 period Si $\partial$-doped QD SL, a 50-period undoped QD SL, and the two control cells. TEM studies revealed that both the 50-period Si $\partial$-doped and the 50-period undoped QD SLs contained a high density of misfit dislocations. Both samples showed reasonably good vertical stacking of QDs. These results suggest that the large reduction in $\mathrm{J}_{\mathrm{SC}}$ in the 25- and 50-period Si $\partial$-doped samples may be related to the Si $\partial$-doping. These two samples also exhibited reduced EQE for wavelengths below $900 \mathrm{~nm}$ in comparison to the other cell structures.

To achieve a high absorption coefficient for the QD $\mathrm{SL}$ cells, we require as high a QD density as possible. This means that one has to grow QD SLs with a large number of periods. If the Stranki-Krastanov strain-induced growth mechanism is used to form the QD SLs, then eventually, as more QD SL periods are added the whole $\mathrm{SL}$ structure will relax by the introduction of misfit dislocations to relieve the misfit strain between the QD SL and the substrate. To overcome this problem, strainbalanced QD SLs will be required. The compressive strain in the QD layers can be compensated by growing tensile-strained barrier layers. By the appropriate choice of materials and layer thickness, a strain-balanced QD SL can be grown that exhibits no net lattice mismatch to the substrate. If strain balance can be achieved, there should be no limit to the number of periods that can be grown in the QD SL. The reduction in dislocation density expected in these strain-balanced structures should also lead to an increase in the $V_{O C}$ of QD SL cells. Such strain-balanced structures, e.g., InGaAs/GaAsP on $\mathrm{GaAs}$ substrates, have been successfully grown previously for quantum-well solar cells [16].

\section{CONCLUSIONS}

We have grown by MOVPE on $\{113\} \mathrm{B}$ GaAs substrates up to 50-period InGaAs/GaAs QD SLs showing both lateral and vertical ordering of QDs and good structural and optical properties. Solar cells incorporating these QD SLs in the absorbing regions show photoresponses extended to longer wavelengths than GaAs and InGaAs/GaAs SL control cells. The QD solar cells show reduced $V_{O C}$ and, in some cases, reduced $J_{S C}$ in comparison to the control cells. Undoped QD SL devices performed better than Si $\partial$-doped devices. To avoid the introduction of harmful misfit dislocations in 
devices with a large number of periods, we may need to grow strain-balanced structures, e.g., InGaAs/GaAsP QD SLs on GaAs substrates.

\section{ACKNOWLEDGEMENTS}

This work was supported by the NREL Director's Discretionary Research and Development (DDRD) Program.

\section{REFERENCES}

[1] M.A. Green, "Third Generation Photovoltaics: Solar Cells for 2020 and Beyond", Physica E 14, 2002, pp. 6570.

[2] M.A. Green. Third Generation Solar Cells: Advanced Solar Energy Conversion, Berlin: Springer-Verlag, 2003.

[3] A. Luque and A. Martí, "Increasing the Efficiency of Ideal Solar Cells by Photon Induced Transitions at Intermediate Levels", Phys. Rev. Lett. 78, 1997, pp. 50145017.

[4] A. Luqe and A. Martí, "A Metallic Intermediate Band High Efficiency Solar Cell”, Prog. Photovolt.: Res. Appl. 9, 2001, pp. 73-86.

[5] A. Martí, L. Cuadra, and A. Luque, "Quantum Dot Intermediate Band Solar Cell", Twenty Eighth IEEE PVSC, 2000, pp. 940-943.

[6] A. Martí, L. Cuadra, and A. Luque, "Partial Filling of a Quantum Dot Intermediate Band for Solar Cells", IEEE Trans. Electron Devices 48, 2001, pp. 2394-2399.

[7] A. Martí, L. Cuadra, and A. Luque, "Quantum Dot Analysis of the Space Charge region of the Intermediate Band Solar Cell", Photovoltaics for the $21^{\text {st }}$ Century, Electrochemical Society Proceedings Volume 2001-10, 2001, pp. 46-60.
[8] A. Martí, L. Cuadra, and A. Luque, "Design Constraints of the Quantum-Dot Intermediate Band Solar Cell", Physica E 14, 2002, pp. 150-157.

[9] C.B. Honsberg and M.Y. Levy, "Theory and Experimental Investigation of Approaches to $>50 \%$ Solar Cells", DOE Solar Program Review Meeting Denver October 2004.

[10] I.N. Stranski and L. Krastanov, Sitzungsber. Akad. Wiss Wien. Math-Naturwiss. Klasse 146, 1937, pp. 797.

[11] V.A. Shchukin, N.N. Ledentsov, and D. Bimberg, Epitaxy of Nanostructures, Berlin: Springer-Verlag, 2004.

[12] V.A. Shchukin, N.N. Ledentsov, P.S. Kopev, and D. Bimberg, "Spontaneous Ordering of Arrays of Coherent Strained Islands", Phys. Rev. Lett. 75, 1995, pp. 19682971.

[13] Q. Xie, A. Madhukar, P. Chen, and N. P. Kobayashi, "Vertically Self-Organized InAs Quantum Box Islands on GaAs(100)", Phys. Rev. Lett. 75, 1995, pp. 2542-2545.

[14] A. Luque, A. Martí, C. Stanley, N. López, L. Cuadra, D. Zhou, J.L. Pearson, and A. McKee, "General Equivalent Circuit for Intermediate Band Devices: Potentials, Currents and Electroluminescence", J. Appl. Phys. 96, 2004, pp. 903-909.

[15] K. Kim, G.L.W. Hart, and A. Zunger, "Negative Band Gap Bowing in Epitaxial InAs/GaAs Alloys and Predicted Band Offsets of the Strained Binaries and Alloys on Various Substrates", Appl. Phys. Lett. 80, 2002, pp. 31053107.

[16] N.J. Ekins-Daukes, K.W.J. Barnham, J.P. Connolly, J.S. Roberts, J.C. Clark, G. Hill, and M. Mazzer, "Strainbalanced GaAsP/InGaAs Quantum Well Solar Cells", Appl. Phys. Lett. 75, 1999, pp. 4195-4197. 


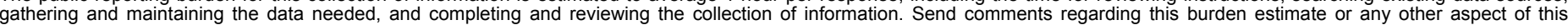

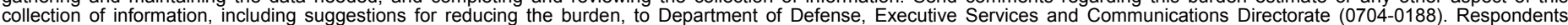

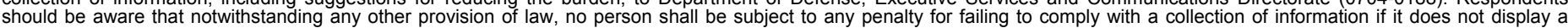

should be aware that notwithstanding

PLEASE DO NOT RETURN YOUR FORM TO THE ABOVE ORGANIZATION.

\section{REPORT DATE (DD-MM-YYYY) \\ February 2005 \\ 2. REPORT TYPE \\ Conference Paper}

4. TITLE AND SUBTITLE

InGaAs/GaAs QD Superlattices: MOVPE Growth, Structural and

Optical Characterization, and Application in Intermediate-Band

Solar Cells
3. DATES COVERED (From - To)

3-7 January 2005

5a. CONTRACT NUMBER

DE-AC36-99-GO10337

5b. GRANT NUMBER

5c. PROGRAM ELEMENT NUMBER

5d. PROJECT NUMBER

NREL/CP-520-37405

5e. TASK NUMBER

PVA53201

5f. WORK UNIT NUMBER
7. PERFORMING ORGANIZATION NAME(S) AND ADDRESS(ES)

National Renewable Energy Laboratory

1617 Cole Blvd.

Golden, CO 80401-3393
8. PERFORMING ORGANIZATION REPORT NUMBER

NREL/CP-520-37405

9. SPONSORING/MONITORING AGENCY NAME(S) AND ADDRESS(ES)

10. SPONSOR/MONITOR'S ACRONYM(S)

NREL

11. SPONSORING/MONITORING AGENCY REPORT NUMBER

12. DISTRIBUTION AVAILABILITY STATEMENT

National Technical Information Service

U.S. Department of Commerce

5285 Port Royal Road

Springfield, VA 22161

\section{SUPPLEMENTARY NOTES}

\section{ABSTRACT (Maximum 200 Words)}

We report on the growth and characterization of InGaAs/GaAs quantum dot (QD) superlattices for application in intermediate-band solar cells (IBSCs). Good optical and structural quality QD superlattices with up to 50 periods were obtained by metal-organic vapor-phase epitaxy (MOVPE) growth on $\{113\} \mathrm{B}$ GaAs substrates. Solar cells containing Si d-doped and undoped QD superlattice absorption regions have been fabricated and their performance compared with control cells containing undoped GaAs or undoped InGaAs/GaAs superlattice absorption regions. The QD superlattice cells exhibited photoresponses extended to longer wavelengths than the control cells. The introduction of QDs to the absorbing region of the solar cells resulted in a decrease in the open-circuit voltages and, in some cases, a decrease in the short-circuit currents of the cells.

\section{SUBJECT TERMS}

PV; growth and characterization; quantum dot (QD); intermediate-band solar cells (IBSCs); metal-organic vaporphase epitaxy (MOVPE); photoresponses; open-circuit voltages;

\begin{tabular}{|c|c|c|c|c|}
\hline \multicolumn{3}{|c|}{ 16. SECURITY CLASSIFICATION OF: } & \multirow{2}{*}{$\begin{array}{l}\text { 17. LIMITATION } \\
\text { OF ABSTRACT } \\
\text { UL }\end{array}$} & \multirow{2}{*}{$\begin{array}{l}\text { 18. NUMBER } \\
\text { OF PAGES }\end{array}$} \\
\hline $\begin{array}{l}\text { a. REPORT } \\
\text { Unclassified }\end{array}$ & $\begin{array}{l}\text { b. ABSTRACT } \\
\text { Unclassified }\end{array}$ & $\begin{array}{l}\text { c. THIS PAGE } \\
\text { Unclassified }\end{array}$ & & \\
\hline
\end{tabular}

\begin{tabular}{l} 
19a. NAME OF RESPONSIBLE PERSON \\
\hline 19b. TELEPHONE NUMBER (Include area code) \\
\hline
\end{tabular}

